\title{
3
}

\section{Asylum Decision-Making in Switzerland}

This chapter sets the scene for the three main analytical chapters of this book by providing a brief outline of how the Swiss asylum procedure works. It introduces readers to the main elements of (Swiss) asylum law that structure SEM officials' decision-making practices and the organisation they work in. Thereby, the chapter, on the one hand, aims to bring out the particularities of the Swiss case. On the other hand, it highlights the many similarities that exist between asylum determination proceedings in Switzerland and those in other countries of the Global North, particularly in Western Europe. Given these similarities, I argue that while empirically, my research focuses on firstinstance asylum decision-making in Switzerland, my analysis, nevertheless, provides insights beyond this specific case study, allowing us to gain a better understanding of asylum decision-making processes more generally.

There are five parts to this chapter. The first part discusses the main developments in Swiss asylum politics since the 1950s and contextualises them within broader global trends. One such trend and, at the same time, consequence of the changing politics, are the numerous adaptations made to asylum law and, connected to this, the proliferation of decision-making categories, which I discuss separately in the second part of this chapter. The third part shows how in the light of global trends in asylum politics, and parallel to the many changes made to Swiss asylum law, a growing - and increasingly specialised-asylum administration emerged: the SEM we know today. What this administration does and how it is organised—or, rather, how it was organised at the time of my fieldwork between 2014 and 2015-is the topic of the fourth part of this chapter. Finally, in the fifth and last part, I discuss 
the legal categorisations decision-making in the SEM ultimately comes down to and outline the relevant articles from Swiss asylum law which constitute the basis for these categorisations.

\section{Asylum Politics in Switzerland and Beyond}

Despite its title, giving a full overview of asylum politics in Switzerland (or globally) is not the aim of this section. That would go beyond the scope of this chapter. What I aim to do instead is to situate developments in asylum politics and decision-making practices in Switzerland since the 1950s within broader trends described in the Global North.

According to Ephraim Poertner,

two contrasting regimes for the government of refugees exist today: collective protection regimes for people who escape wars and persecution across national borders and are commonly hosted in camps in neighbouring countries - these are typical for the global South; and individual protection regimes concerned with people seeking admission common in wealthy states of the global North. (2018: 5; see also Fassin and Kobelinsky 2012: 448)

I find this distinction useful for two reasons, first, because it reminds us of an important fact, namely that the vast majority of people seek protection in countries of the Global South. Comparatively very few people apply for asylum in Switzerland or Europe in general. Second, different terminologies are used for the people seeking protection in these regimes. As Poertner, building on Didier Fassin (2016a: 66-67), argues, in collective protection regimes "people are collectively regarded as 'refugees' because they fled their countries of origin or residence" (Poertner 2018: 5). In contrast, in individual protection regimes, people are considered as “individual 'asylum seekers' whose 'well-founded fear of persecution' has to be examined in a laborious administrative procedure before they may become "refugees' legally" (ibid.; see also Jubany 2017: 45). Hence, the terms "refugees" and "asylum seekers" carry different, specific political meanings (see also Zetter 2007: 180). Rather than merely reflecting a difference in status, the two terms represent "a fundamental difference of recognition", as Fassin argues (2016b). Because the focus of this book is on decision-makers' perspectives, I employ the emic terminologies decision-makers themselves use to refer to the people they are dealing with. Thus, I use the terms "asylum seekers", "applicants" and "claimants", also because they fittingly describe people's positions in the legal proceedings at work in countries of the Global North. However, I do not wish to imply 
that I do not consider these people to be refugees in the broader sense of the term described above. To the contrary, they are all people who have fled their country of origin or of residence and are in need of protection.

As is common in the Global North, the Swiss asylum system is based on the administrative assessment of individual asylum claims. Figure 3.1, which I have taken from Ephraim Poertner's thesis "Re-cording Lives: Governing Asylum in Switzerland and the Need to Resolve" (2018), illustrates the number of such individual asylum applications filed in Switzerland each year between 1968 and 2017.

We can see that in the 1980s and 1990s, there was an increase of people seeking asylum in Switzerland. Simultaneously, as the red line indicates, there is a sharp decline in the number of people receiving asylum. Before the 1980 s - or, more specifically, between the 1950s and 1980s-asylum was generally granted. This was mostly related to the fact that people applying for asylum had fled communist states (see D'Amato 2008: 178; Däpp 1984; Efionayi-Mäder 2003: 3-4; Haug 1984; Parini and Gianni 2005: 196-201; Piguet 2006: 87-95, 2009: 70-77). Furthermore, in addition to Switzerland's anti-communist stance in the Cold War period; the booming economy at the time (and consequently Switzerland's need for extra labour power) was also a decisive factor for this "welcome reception". Moreover, according to Heinz Däpp, there was also a strong desire at that time, for Switzerland to compensate for its restrictive refugee policy during the Second World War (1984: 212). This so-called "open arms policy" (Piguet 2006: 91) towards people fleeing communist countries continued throughout the 1980s. However,

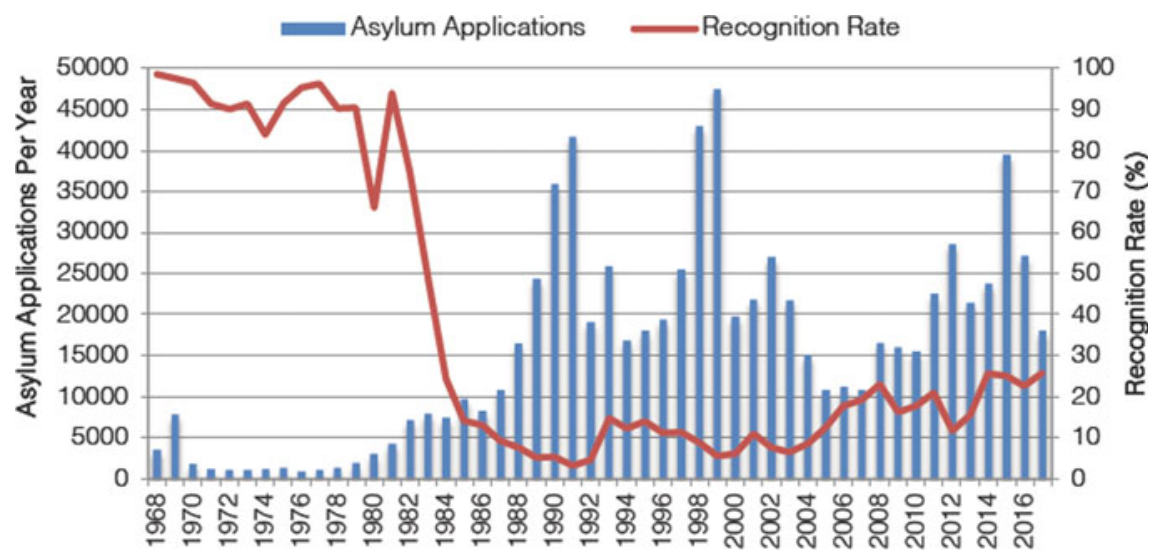

Fig. 3.1 Number of asylum applications and recognition rates between 1968 and 2017 (Source Poertner 2018: 5) 
while this was happening, Swiss asylum policies were becoming more restrictive towards other refugees. This meant that, in 1973, following Pinochet's coup d'état, when the UNHCR urged countries to receive Chilean refugees, Switzerland reneged on its "open arms policy", because these were now the "wrong" refugees: these were leftists and communists (Meiner 2007: 119; see also D'Amato 2008: 178; Piguet 2009: 77). In the end, the Swiss government, after much pressure from leftist organisations and churches, granted protection to 255 Chilean refugees. Yet, this was a first step towards a more restrictive asylum and refugee policy which has continued ever since. In their analyses of asylum politics in Switzerland, Heinz Däpp (1984), Werner Haug (1984) and Etienne Piguet (2006) identify two main reasons for asylum policies becoming stricter at that time. Firstly, the refugees that started to arrive in the 1980s, no longer neatly fitted into the East/West divide. Secondly, the economic crisis following the 1973 oil crises led to increased unemployment and a ban on labour immigration which restricted possibilities (other than asylum) for gaining residency in Switzerland. In addition, in his detailed analysis, Jonathan Miaz (2017: 79-83) shows how the discourse on Überfremdung (foreign domination or infiltration) became increasingly dominant in Swiss politics in the 1970s and eventually merged with the discourse on asylum.

Very similar developments to those of Switzerland are also described for France by Didier Fassin (2016b) and Carolina Kobelinsky (2015), and for the UK and Europe in general by Olga Jubany (2017: 44-46). These authors describe an increase in the number of people applying for asylum in the 1980s with a simultaneous sharp decline in the recognition rate. In order to explain these changes, they identify the same reasons described above in the case of Switzerland: less need for labour power following the economic crisis in the 1970s and refugees no longer fitting clearly into the East/West divide. In their work, Didier Fassin and Carolina Kobelinsky thereby challenge the common interpretation that the rise of asylum applications following the closure of borders for immigration in the mid-1970s is a sign of "immigrants attempt[ing] to pass themselves off as refugees" (Fassin and Kobelinsky 2012: 449). Rather, Carolina Kobelinsky argues (in the context of France), that this interpretation

ignores two important explanatory factors: the lifting of temporal and spatial restrictions of the Geneva Convention, and the fact that until the formal interruption of labour immigration in 1974 it was easier to obtain a work permit than refugee status. As a result, many potential applicants for refugee status under the Convention did not claim for asylum, as they already had legal residence in France. (2015: 72; see also Fassin and Kobelinsky 2012: 449) 
Given that the historical accounts on asylum politics in Switzerland discussed above also describe a strong need for labour power in the 1950s and 1960s, as well as the introduction of an immigration labour ban following the economic crisis in the 1970s, it seems plausible that Kobelinsky's argument also applies to the Swiss context, at least to some extent. Switzerland ratified the 1951 Convention relating to the Status of Refugees (often referred to as the Geneva Convention) in 1955 and later also the 1967 Protocol which removed the temporal and geographical restrictions of the original Convention by extending the definition of refugeehood to encompass people fleeing from outside Europe and also due to events taking place after 1951.

Today, in the Global North, the "fight against abuse", as it is often referred to, is high on the political agenda, accompanied by a widespread discourse on so-called "false" or "bogus refugees" (see Däpp 1984: 216-219; Fassin 2007; Zimmermann 2011). Asylum seekers and migrants in general are often portrayed as a "problem" in today's political discourse and media. They are seen as a "threat" to states' economy, culture and identity (see Dahlvik 2018: 9; Gill and Good 2019: 5-6; Miaz 2017: 11-12). Furthermore, they are increasingly depicted as a "threat" to the safety of countries and their citizens, which serves to justify heightened securitisation measures such as the externalisation of border controls and the restriction of access to refugee determination procedures (see Boswell 2007: 589; Dahlvik 2018: 9; Huysmans 2000; Jubany 2017; Miaz 2017: 13-14; Stünzi 2010). Asylum determination procedures in the Global North today are, therefore, structured around a "politics of deterrence" (Poertner 2017; see also Hamlin 2014; Poertner 2018: 282-287), with no country wanting to be more generous in granting asylum and subsidiary protection than others in order not to create a so-called "pull-effect" (see Fuglerud 2004: 33; Jubany 2017: 62; Liodden 2016: 219; Miaz 2017: 15, 343; Poertner 2017: 17, 283). Indeed, in the initial training sessions for new SEM decision-makers in which I took part, on the very first day, those present were told by a trainer: "You are going to hear this often from now on: We are always afraid of the 'pull-effect"'. ${ }^{1}$

In Switzerland, this politics of deterrence is linked to the discourse on Überfremdung (foreign domination or infiltration), which as Jonathan Miaz's careful analysis of asylum politics in Switzerland shows, has a long tradition in Swiss German-speaking right-wing politics. For example, the Nationale Aktion gegen die Überfremdung von Volk und Nation (the national action against foreign infiltration of the nation and homeland) was founded in Switzerland in 1961. The party subsequently launched several initiatives

\footnotetext{
${ }^{1}$ Training instructor, A-modules, field notes, my own translation.
} 
against $\ddot{U} b e r f r e m d u n g$, aimed at laying down fixed quotas for the percentage of foreigners in Switzerland. In the 1950s and 1960s, this discourse of Überfremdung was mainly aimed at so-called "guest workers" from Italy and Spain, who were perceived as a threat to national identity. In contrast, asylum seekers were, at that time, perceived as victims. However, in the 1970s and 1980s different right-wing parties started transferring the discourse of Überfremdung onto the issue of asylum, increasingly portraying asylum seekers as a threat for Switzerland (Miaz 2017: 79-83). While the discourse of Überfremdung itself has not really transferred out of right-wing politics, the "fight against abuse", which is very much linked to this discourse, has since then been adopted and put on the political agenda by several "mainstream" political parties too (ibid.: 87-90). It has been the drive behind, and a legitimation for, many of the changes made to Swiss asylum law over the past forty years.

\section{Changing Law and the Proliferation of Legal Categories}

Since its introduction in 1981, the Swiss Asylum Act has been adapted more times than any other Swiss law ever has in such a short time period (Maillard and Tafelmacher 1999: 103; Piguet 2009: 84). ${ }^{2}$ Such frequent legislative changes to asylum and migration law are not specific to Switzerland and have been described for other European countries too (see Boswell 2003; Eule 2014: 43; Eule et al. 2019: 41-42). What is, however, specific about the Swiss case is that several of the changes to Swiss asylum law were made as the result of political referenda (see Miaz 2017: 16). In addition to the "fight against abuse" and the idea of deterrence, Jonathan Miaz identifies the will to accelerate asylum procedures as a further leitmotiv behind the many adaptations of the Swiss Asylum Act (2017: 2). To go into all these changes in detail would go beyond the scope of this chapter, but a detailed analysis can be found in Miaz's doctoral thesis "Politique d'asile et sophistication du droit" (2017). In short, the general tendencies of these changes include the introduction of new reasons for rejecting asylum claims, the introduction of new evidentiary requirements as well as restrictions to the possibilities of claiming asylum in the first place and the creation of particular obstacles for appealing asylum decisions (Miaz 2017: 2). The following table shows some of these changes which best illustrate these major trends (Fig. 3.2).

\footnotetext{
${ }^{2}$ Substantial changes were made to the Asylum Act in 1983, 1984, 1986, 1990, 1992, 1994/1995, 1996, 1998, 1999, 2003, 2005/2006, 2008, 2012, 2014, 2015 and 2016 (see Miaz 2017: 95-96; Piguet 2006: 106; Schweizerische Flüchtlingshilfe SFH 2009: 31-38).
} 


\begin{tabular}{|c|c|}
\hline 1984 & $\begin{array}{l}\text { - The asylum procedure is shortened. } \\
\text { - In so-called "evidently unfounded cases" the procedure can be shortened by } \\
\text { not conducting a second longer interview. } \\
\text { - It is no longer possible to appeal asylum decisions at the Federal Tribunal. }\end{array}$ \\
\hline 1986 & $\begin{array}{l}\text { - Rejected asylum seekers can be detained up to } 30 \text { days pending deportation. } \\
\text { - The cantons are allowed to issue a three-month working ban for asylum } \\
\text { seekers. }\end{array}$ \\
\hline 1990 & $\begin{array}{l}\text { - Applications by people from so-called "safe countries" now lead to a } \\
\text { "dismissal without entering into the substance of the case" (DAWES-decision.) } \\
\text { - The Asylum Appeals Commission (Asylrekurskommission), an independent } \\
\text { appeal board (which later becomes the Federal Administrative Court) is created. } \\
\text { - The cantons are allowed to stretch the working ban for asylum seekers to six } \\
\text { months. }\end{array}$ \\
\hline 1999 & $\begin{array}{l}\text { - If applicants do not hand in any identity papers (or render credible why they } \\
\text { cannot), this leads to a DAWES-decision (see above). }\end{array}$ \\
\hline 2006 & $\begin{array}{l}\text { - If applicants do not hand in any identity papers within the first } 48 \text { hours of } \\
\text { applying for asylum (or render credible why they cannot), this leads to a } \\
\text { DAWES-decision. } \\
\text { - The deadline for appealing DAWES-decisions is lowered from } 30 \text { to five } \\
\text { days. } \\
\text { - All rejected asylum seekers are no longer entitled to social welfare. They now } \\
\text { only receive emergency aid according to article } 12 \text { of the Federal Constitution } \\
\text { of the Swiss Confederation, which states that "Persons in need and unable to } \\
\text { provide for themselves have the right to assistance and care, and to the financial } \\
\text { means required for a decent standard of living". }\end{array}$ \\
\hline 2008 & - The Schengen Agreement and Dublin Regulation comes into effect. \\
\hline 2012 & $\begin{array}{l}\text { - People who "have refused to perform military service or have deserted" and } \\
\text { claim for asylum on these grounds are excluded from refugee status as well as } \\
\text { people "who claim grounds based on their conduct following their departure } \\
\text { that are neither an expression nor a continuation of a conviction already held in } \\
\text { their native country or country of origin" (Art. 3, paragraphs } 3 \text { and 4, AsylA). }\end{array}$ \\
\hline
\end{tabular}

Fig. 3.2 Changes to asylum legislation between 1984 and 2012 (Source My own summary). The information I use here comes from Miaz (2017: 92-97) and from the SRF News website (https://www.srf.ch/news/schweiz/abstimmungen/abstimmungvom-9-6-2013/asylgesetz/chronologie-asylrecht-sukzessive-verschaerft, last accessed 29.01.2020). The dates I refer to in the table are from when the decision to make the changes was taken (mostly by parliament or by political referendum). However, some of those changes only came into effect a year or more later 
A consequence of the changes made to asylum law has been the proliferation of legal categories or labels of protection, a trend which has been described for the Global North in general (see Poertner 2018: 5; Zetter 2007). The graph below, which was created by Jonathan Miaz, nicely illustrates this for Switzerland.

The dark blue bars indicate the percentage of asylum claims being granted, while the orange bars show the proportion of rejected asylum claims. The red and green bars - the latter are only barely visible - show the percentage of so-called DAWES decisions. DAWES stands for "dismissal without entering into the substance of the case". The red bars are DAWES decisions without temporary admission, the nearly invisible green bars are DAWES decisions with temporary admission. Rejected asylum claims with temporary admission are marked in light blue. The yellow bars show the percentage of Dublin decisions. While before 1986 there were only two possible outcomes of decision-making: people were either granted asylum or their claims were rejected, we can since then observe a multiplication of legal categories. In 1986, the legal status of temporary admission was created. This came at a time of rising numbers of rejected asylum seekers who could nevertheless not be deported either under international law or for humanitarian and technical reasons (Sille 2016: 22-24). The emergence of this category fits with what Didier Fassin has called the "humanitarianization of asylum", a kind of "substitution of a right to asylum by an obligation in terms of charity" (2005: 387; see also Fassin 2012). In one of the training courses for new decision-makers that I attended, this understanding was taught to the novices in very explicit terms: "Temporary protection is not a right, but a service [Dienstleistung] we provide", the instructor announced. ${ }^{3}$ Today in countries of the Global North, such forms of subsidiary protection are granted more frequently than asylum. In the Swiss case, subsidiary protection is further divided into subcategories, as I will discuss later on in this chapter. Figure 3.3 shows the emergence of DAWES decisions in 1990, when this category was newly introduced. We can see how in 1999, when the lack of identity papers was added as a reason for rejecting asylum claims without going into the substance of the case, the number of DAWES decisions significantly increased. After most reasons for taking such decisions were abolished in 2014, in turn, there is a sharp decline. In 2009, we can see the new category of "Dublin decisions" emerging after the Schengen Agreement and Dublin regulation came into effect in Switzerland in December 2008. This agreement, amongst other things, "regulates which member state is responsible for processing an application for

\footnotetext{
${ }^{3}$ Training instructor, A-modules, field notes, my own translation.
} 


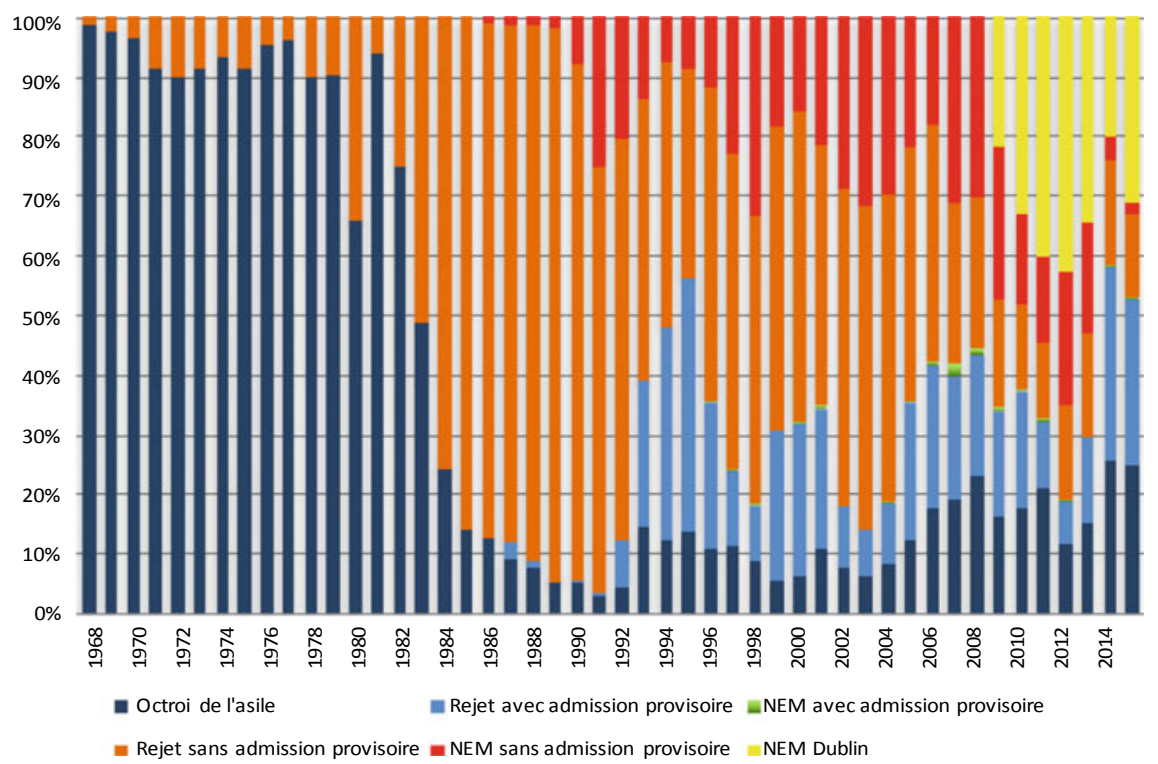

Fig. 3.3 The proliferation of legal categories and first instance asylum decisions between 1968 and 2015 (Source Miaz 2017: 168)

asylum": normally the first country in the so-called "Schengen/Dublin" area an applicant enters, or is registered by. ${ }^{4}$

This proliferation of legal categories, together with the increased complexity in asylum law and the growing numbers of asylum applications (especially in the early and late 1990s due to the wars in the Balkan region), has led to the emergence of an increasingly specialised office called the SEM, as I will go on to discuss.

\section{The SEM: A Specialised Asylum Administration Emerges}

You know, thirty years ago this office was a mere section of the Federal Office of Police, the fedpol, just a section. And then when I started [working here] it was the Office of the Delegate for Refugees (Amt des Delegierten für das Flüchtlingswesen). That was more like a task force. The idea was to deal with

\footnotetext{
${ }^{4}$ https://www.refugeecouncil.ch/asylum-law/legal-basis/schengendublin-and-switzerland.html, last accessed 03.02.2020, see also: https://www.sem.admin.ch/sem/en/home/asyl/dublin.html, last accessed 03.02.2020.
} 
the asylum business and to just get it over and done with. And then [...] later it was merged with the Federal Office for Foreigners and became the Federal Office of Migration and now we're a State Secretariat. Do you see? In thirty years we have gone from being a single section to being a State Secretariat. That explains a lot of things. ${ }^{5}$

In this quote, SEM caseworker Peter accurately summarises the development of the office in charge of dealing with asylum applications since 1981. He shows how since 1981 the office has gone from being a small section within the Federal Office of Police (fedpol) to a State Secretariat, making its director one of the six State Secretaries in Switzerland. The first office in charge of taking asylum decisions was set up in 1981 when the first Swiss Asylum Act came into effect. At that time, the office was a mere section within the Federal Office of Police (fedpol). Being part of the fedpol, the office formed part of the Federal Department of Justice and Police (FDJP), as the SEM still does today. The FDJP is one of seven government departments in Switzerland, each of which is led by one of the seven Federal Councillors which constitute the country's executive. In 1985, the Federal Councillor then in charge of the FDJP founded a new office, the Office of the Delegate for Refugees, with the clear aim of dealing with "the refugee problem" (Kopp 1987). The idea was that this office would exist for a maximum of ten years and that by then "the problem" would be "solved" (Miaz 2017: 98). Apart from taking asylum decisions, it was the office's duty to coordinate the work of the federal government with the cantons and different NGOs working with refugees. It was also in charge of cooperating with international actors and preparing the Swiss state for possible future "problems" (Kopp 1987). By 1990, it was clear that a more long-term "solution" was needed and the Federal Office for Refugees was set up. While the Federal Office for Refugees still formed part of the FDJP, it was no longer a part of the fedpol itself. Fifteen years later, in 2005, the then responsible Federal Councillor, in an attempt to substantially reduce administrative costs, merged the Federal Office for Refugees with the Federal Office of Immigration, Integration and Emigration, which together became the Federal Office of Migration. With this merger, the Councillor's main aim was to steer Switzerland's migration politics in a more "holistic and consequent" way. ${ }^{6}$ As can be seen in a media communiqué presented by the FDJP at the time, the merger was meant to solve the "problems that exist nowadays in the 'fields of asylum and foreigners'

\footnotetext{
${ }^{5}$ Peter, caseworker, headquarters, interview transcript, my own translation.

${ }^{6} \mathrm{https} / /$ www.sem.admin.ch/sem/de/home/aktuell/news/2004/ref_2004-06-07.html, last accessed 30.01.2020.
} 
(Asyl- und Ausländerbereich) [...] in a more effective and economic way". ${ }^{7}$ Furthermore, the communique states that the aim of the consolidation of the two offices was to be better able to "combat abuse", which clearly reflects the global trends described above. The merger exemplifies how asylum has increasingly become a "vector of immigration", as Carolina Kobelinsky has argued (2015: 87). Finally, on 1st January 2015, in the midst of my fieldwork, the Federal Office of Migration became a State Secretariat in order to "take account of the growing importance of the SEM's work and its expanding range of tasks". ${ }^{8}$ A further reason for this "upgrading" was to strengthen the office director's position in international negotiations and place him on the same level as the representatives from other countries so he would better be able to represent Switzerland's interests. ${ }^{9}$ Before the Federal Office of Migration (FOM) became the State Secretariat for Migration in 2015, there were only four State Secretaries: one responsible for foreign affairs, one for international finance issues, one for economy and one for education and research. ${ }^{10}$ It seems noteworthy that this change came at a time when Switzerland began negotiating the issue of free movement of people (Personenfreizügigkeit) with the EU following the acceptance of the referendum "against mass immigration" (Masseneinwanderungsinitiative) by a majority of the electorate in 2014.

The institutional changes I have described so far are those which led to name changes of the first-instance asylum administration in Switzerland. In addition, there have also been several other structural reforms. For instance, in September 2013, all the asylum units at the SEM headquarters in Bern were newly put together. While before, decision-makers had worked in socalled regional teams, meaning that each unit specialised in dealing with applications from asylum seekers from specific regions, from September 2013 onwards all of the newly constituted teams were requested to deal with 'cases' from everywhere. When I started doing fieldwork in the SEM in early 2014, some of the teams had because of that only quite recently started working together. A rather substantial restructuration, furthermore, occurred in March

\footnotetext{
${ }^{7}$ https://www.sem.admin.ch/sem/de/home/aktuell/news/2004/ref_2004-06-07.html, last accessed 30.01.2020.

${ }^{8}$ https://www.sem.admin.ch/sem/en/home/ueberuns/sem.html, last accessed 30.01.2020.

${ }^{9}$ https://www.ejpd.admin.ch/ejpd/de/home/aktuell/news/2014/2014-09-191.html, last accessed 31.01.2020.

${ }^{10}$ In 2018, the Directorate for European Affairs was created and its director became the sixth State Secretary.
} 
2019, thus well after I had completed my fieldwork. ${ }^{11}$ While this last reform has led to significant changes in the administration's organisational structure and some procedural aspects have slightly changed, the core of SEM decisionmakers' work has not: decision-makers still conduct asylum interviews and assess asylum seekers' eligibility to refugee status as well as their credibility, which is what this book is mainly about. The procedural and structural organisations I describe in this book reflect matters as they stood at the time of my research in 2014 and 2015. However, before turning to these descriptions, I would like to briefly highlight some of the major changes introduced by the 2019 reform.

The main aim of the 2019 reform was to accelerate the procedure for which three principal reasons were given: first, to get rejected asylum seekers to leave the country as fast as possible; second, to ensure that asylum seekers do not have to wait for years to receive their decision so that they can be more quickly "integrated into society" ${ }^{12}$; and third, to cut government costs. ${ }^{13}$ Today, the new accelerated procedure lasts for a maximum of 140 days, with sixty to seventy per cent of all asylum applications being dealt with in this way. The remaining thirty to forty per cent of all asylum applications-namely, those deemed more complicated and needing more time to be examined-are assigned to the extended procedure which works more or less the same way as the "regular" procedure did at the time of my research. The accelerated procedures take place in so-called "federal centres" (Bundeszentren) located in six different regions in Switzerland. Apart from accommodating the asylum seekers, these centres also house SEM decisionmakers and legal advisors. Asylum seekers have access to free legal advisors who accompany the former throughout the whole procedure. Before the 2019 reform, it was uncommon for asylum seekers to have legal representation during the first-instance proceedings with legal advice services being provided by different NGOs mainly at the appeal level. However, there used to be so-called "social aid representatives" (Hilfswerksvertretungen) present during the asylum interviews in the old procedures. These social aid representatives - whose function I will describe in more detail below- have now been replaced by the new "in-house" legal advisors. Moreover, another substantial

\footnotetext{
${ }^{11}$ This last reform was set in motion after it had been "accepted by two-thirds of [the] voters in a nationwide ballot in 2016" (https://www.swissinfo.ch/eng/explainer-_how-well-does-the-new-swiss-asy lum-system-work--/45360318, last accessed 31.01.2020).

${ }^{12}$ https://www.swissinfo.ch/eng/explainer-_how-well-does-the-new-swiss-asylum-system-work--/453 60318, last accessed 31.01.2020.

${ }^{13}$ See: https://www.swissinfo.ch/eng/explainer-_how-well-does-the-new-swiss-asylum-system-work--/ 45360318, last accessed 31.01.2020 and https://sem.media-flow.ch/asylverfahren-de\#12, last accessed 31.01.2020.
} 
change induced by the reform has been to drastically cut the deadline for appealing first-instance asylum decisions to the Federal Administrative Court: from thirty days down to seven days for those asylum seekers going through the accelerated procedure. For those assigned to the extended procedure, the deadline remains at thirty days. ${ }^{14}$

In the remaining parts of this book, I will not deal with this accelerated procedure but rather look at the "regular" procedure as it existed until early 2019. Most steps of the decision-making procedure and the legal requirements for receiving asylum have remained the same. What I describe in this book is, therefore, still relevant for understanding asylum decision-making in Switzerland today. Furthermore, the Swiss asylum decision-making procedure shares many characteristics with other initial asylum decision-making proceedings in the Global North: the proceedings are inquisitorial in design, credibility determination plays a crucial role and is based on a special standard of proof, and the legal refugee definition is based on the one from the 1951 Refugee Convention and 1967 Protocol (see Johannesson 2017: 13; Poertner 2018: 6). Hence, my analysis also contributes to understanding processes and practices of asylum decision-making more generally.

\section{The Decision-Making Procedure}

The SEM is, according to its website, "responsible for all matters covered by legislation on foreign nationals and asylum seekers in Switzerland". ${ }^{15}$ The organisation defines its main tasks as follows:

The SEM determines under what circumstances a person may enter Switzerland to live and work. It also decides who is granted protection from persecution. In collaboration with the cantons, the SEM organises the accommodation of asylum seekers and the return of people who do not need protection to their country of origin. It also co-ordinates the integration of foreign nationals into Switzerland, is responsible for naturalising foreigners and works actively at an international level to control migration movements. ${ }^{16}$

In "Economy and Society", Max Weber identifies both the "clearly defined hierarchy of offices" and the clear division of competences and tasks as typical

\footnotetext{
${ }^{14}$ See: https://www.swissinfo.ch/eng/explainer-_how-well-does-the-new-swiss-asylum-system-work--/ 45360318, last accessed 31.01.2020 and https://sem.media-flow.ch/asylverfahren-de\#12, last accessed 31.01.2020, https://www.fluechtlingshilfe.ch/asylgesetzrevision.html, last accessed 31.01.2020.

${ }^{15} \mathrm{https} / /$ www.sem.admin.ch/sem/en/home/ueberuns/sem/aufgaben.html, last accessed 02.02.2020.

${ }^{16}$ https://www.sem.admin.ch/sem/en/home/ueberuns/sem.html, last accessed 02.02.2020.
} 
characteristics of bureaucracy (Weber 2013 [1978]: 220). Both these features are characteristic of the SEM.

This book considers the work which is done within one of the SEM's four directorates: the asylum directorate. More specifically, I did all my fieldwork in three of this directorate's divisions: "Asylum I", "Asylum II" and "RPC". "RPC" stands for reception and processing centres, whose function I will describe in detail below. The directorate "Asylum" is the biggest directorate in the SEM and the three divisions I studied were, at the time of my research, those with the most staff. This was clearly evident when I attended a "welcome day" for new SEM employees in early 2014. There were twenty-five new employees present that day of whom twenty were destined for the asylum directorate while the other five were headed to the other three directorates.

The asylum directorate is responsible for first-instance asylum proceedings in Switzerland. It is charged with examining all asylum applications and reaching first-instance decisions. At the second instance, these decisions can then be appealed at the Federal Administrative Court. The Federal Administrative Court is the first, and simultaneously the last, appeal board in Switzerland. Negative judgements by the court cannot be appealed on a national level any further. Thereafter, the only remaining possibility is to file an appeal against Switzerland at the European Court of Human Rights. ${ }^{17}$ The SEM's asylum directorate's duties are, to a great extent, limited to the asylum decision-making proceedings. Consequently, the provision of accommodation for asylum seekers and providing social welfare, for example, are duties which are carried out by other actors. Organisations (both profit and nonprofit) are commissioned by the SEM to provide these "services" in the RPCs (or today in the Bundeszentren) or they are commissioned by the cantons once asylum seekers have been assigned to them. The cantons are also responsible for executing removal orders - or, to put it more bluntly, for detaining and deporting rejected asylum seekers—and for many questions concerning asylum seekers' stay (such as their right to employment).

At the time of my research, the majority of asylum applications were filed at the RPCs. Even if the RPCs have now been replaced by the Bundeszentren and do not exist as such anymore, I will proceed to describe the proceedings in the RPCs in the present tense for better readability. In RPCs, asylum seekers' personal data is recorded, their photos and fingerprints are taken, and a medical examination is carried out by security, medical or otherwise

\footnotetext{
${ }^{17}$ In some cases, asylum seekers can make use of what are called "extraordinary legal remedies" (ausserordentliche Rechtsmittel): a request for a revision of the judgement by the Federal Administrative Court or for a "reconsideration" (Wiedererwägung) of the claim by the SEM on the basis of article 66 of the Federal Act on Administration Procedure (APA).
} 
specialised staff. Their fingerprints are then checked against the EuroDac (European Dactyloscopy) database in order to see whether the applicant has been registered in any of the other signatory states of the Schengen Agreement. On the basis of this, a case file is opened up, which is randomly assigned to a decision-maker at the RPC. Days, or sometimes weeks later, this decision-maker summons the asylum seeker to the first (short) asylum interview: the Befragung zur Person (the interview about the applicant's identity). Other than the decision-maker and the asylum seeker, only an interpreter may be present during these interviews. Thus, the decision-makers themselves write the minutes of the interview. In these first interviews, the asylum seekers are questioned about their personal data (e.g. family ties, education, place of residence, etc.) as well as their reasons for applying for asylum and their travel routes. Often in these interviews, decision-makers probe with a detailed "country test" to try and ascertain whether the asylum seekers "really" are from where they claim. This is because, after the first interview, the decisionmaker has to assign the 'case' to one of three identity categories: A, B or C. Category A indicates that there is "valid" (rechtsgenüglich) proof of identity. Category B concedes that, although there is no valid proof of identity, the caseworkers have no serious doubts about the applicant's country of origin. Category $\mathrm{C}$, on the other hand, indicates that caseworkers suspect the applicants' declared "country of origin" to be untrue because they question the authenticity of identity documents and/or find that the asylum seekers have "insufficient knowledge" about their "country of origin" or that there are "linguistic indicators" that the asylum seekers might be from somewhere else other than what they have said. My analysis of random case files suggests that the majority of case files are assigned to category B, or at least that was true at the time of my fieldwork. The classification of 'cases' into the category $\mathrm{C}$ usually leads to a so-called LINGUA report being requested before the case file is passed on to a decision-maker for taking further procedural steps. LINGUA reports are done by so-called external experts, which are contacted by the LINGUA unit of the SEM, "a specialised unit for analysis of origin". The unit's—or rather its experts'- task is to

carry out analyses of origin for people seeking asylum and for other foreigners. [...] It is the aim of the analysis of origin to determine the country and/or region or, at least, the milieu, which have had the biggest influence on the subject in his/her process of socialization. It is for this purpose that the subject's 
speech as well as his/her cultural knowledge of the region concerned are examined. $^{18}$

In addition to assigning 'cases' to the three identity categories, after the first interview, decision-makers also have to indicate if (they think) the 'case' they are dealing with falls within the Schengen/Dublin regulation or is a socalled GespeVer (gender-based persecution) 'case'. All forms of violence, harm and discrimination experienced by the applicants on the basis of their gender identity and sexual orientation are considered gender-based persecution by the SEM. ${ }^{19}$ According to Article 6 of the Asylverordnung 1 über Verfahrensfragen ("Regulation 1 on Asylum"), in the case of gender-based persecution, the asylum interview must be conducted by a decision-maker of the same gender as the applicant and only in the presence of people (the social aid representative, interpreter and minute-taker) of the same gender (see Art. 6, AsylV1).

All these assessments-what identity category a 'case' is assigned to and whether it is a GespeVer or Dublin 'case' or not-impact upon where the case file is next sent and how it is dealt with further. This first "triage", as it is called, falls within the jurisdiction of the heads of the different units at the RPCs. They decide whether the file is sent to the headquarters, stays at the RPC or goes to the Dublin unit. Exactly which 'cases' are kept at the RPCs and which are sent to the headquarters remained a slight puzzle to me throughout my fieldwork. Mostly, this was because my interaction partners-including the heads-were often confused themselves about the current practice, which they told me kept changing. The heads at the RPCs triage the files according to a list which states for each "country of origin" whether the case file has to be sent to the headquarters or not. On the lists, the countries are classified into different "priority categories". When I first started doing research in the SEM, there were three such "priority categories". 20 "Priority 1 " were countries, to which applicants could ('easily') be deported back. In turn, countries were classified as "priority 2" if deportations were possible but complicated and costly (aufwändig). "Priority 3" countries were those to which deportations were not possible, and only so-called "voluntary returns" (see Loher 2020) could be affected. Decision-makers at the reception centres mostly dealt with "priority 1 cases", while the 'cases'

\footnotetext{
${ }^{18}$ https://www.sem.admin.ch/sem/en/home/publiservice/service/sprachanalysen/lingua.html, last accessed 02.02.2020.

${ }^{19}$ See SEM manual "Asyl und Rückkehr", article D2, https://www.sem.admin.ch/dam/data/sem/asyl/ verfahren/hb/d/hb-d2-d.pdf, last accessed 02.02.2020.

${ }^{20}$ See also Ephraim Poertner (2018: 172-173, 283-284) for a discussion of the priority categories in the SEM.
} 
assigned to the other two categories were sent to the headquarters. Later on during my research the situation changed, with the three "priority categories" being reduced to two categories. "Prio 1 cases" then became those 'cases' that would most likely be decided negatively (e.g. claims by applicants from countries with very low recognition rates, claims by applicants coming from so-called "safe countries" or through a "Dublin country", claims by applicants who have committed a crime, etc.), while all others became "second priority cases". With "prio 1 cases", the decision-makers were requested to work according to the principle "last in, first out". With second priority 'cases', in turn, the guiding principle was "first in, first out". Ephraim Poertner has argued that these principles function as measures of deterrence. Thus, "for the first group of claimants, deterrence is considered to work best with a prompt negative decision and a threat of expulsion [...]. And for the second group of claimants, who are likely to receive protection, deterrence works through the suspension of benefits until asylum is finally granted" (2017: 19).

During my research, it seemed that many of the "prio 1 cases" remained at the RPCs to be dealt with while a large proportion of the other priority categories were sent to the headquarters. However, as officials, both at the headquarters and at the RPCs, told me repeatedly, this division was not as strict as it had formerly been, leading to "everyone doing everything". Nevertheless, my impression was that 'cases' submitted by applicants from countries where fewer asylum seekers come from were often sent to the headquarters as well as 'cases' which were deemed to be "very complex" and "time-consuming".

Once the files are assigned to a specific section, either at the headquarters or the RPCs, it is up to the head of this section to allocate the 'cases' to one of their employees or to send them to the archives for a while. Some cases, instead of going directly to a decision-maker, are first given to a so-called "pooly". The name "pooly" derives from the fact that these people belong to a pool of interviewers who only conduct asylum interviews but do not take any decisions. "Poolies" do not belong to the SEM's regular staff, but are rather paid by the hour to conduct asylum interviews. Like decision-makers, "poolies" carry out the second longer asylum interviewswhich may take place weeks, months or, in some cases, even years after the first short interview. In these interviews, the decision-makers or "poolies" interrogate the asylum seekers in detail about their reasons for fleeing and for applying for asylum in Switzerland. In rare cases, a third supplementary interview is carried out. A minute-taker and a social aid representative join the decision-maker (or "pooly"), the asylum seeker and the interpreter in the longer second and third interviews. As the job title indicates, social aid 
representatives work for different NGOs active in the field of asylum. Their job is to "observe the procedure from a neutral perspective". Furthermore, they can "have the SEM [officials] ask the asylum seekers about certain issues or pose the questions themselves, express objections and urge additional clarifications". ${ }^{21}$ At the end of the interview, they fill in a form, which is stapled to the minutes of the interview and goes in the case file. On the forms they can note any particular observations they made during the interview, suggest further investigations (e.g. a medical examination), and state any objections they might have to the minutes. Finally, they write a report for the organisation they work for and for the Swiss Refugee Council (Schweizerische Flüchtlingshilfe) which is the umbrella organisation of all refugee organisations in Switzerland, coordinating social aid representatives' work in the asylum procedures. On these forms, the social aid representatives must, amongst other things, assess the 'case' (and indicate if they think it was credible or not and predict whether it will probably lead to asylum or not). These forms are sometimes used by lawyers and legal advisors when filing an appeal against a negative decision with the Federal Administrative Court. At the end of the second and sometimes third asylum interviews, the minutes are read back to the asylum seeker by the interpreter. The asylum seeker has to sign every page in order to prove the veracity of the recorded statements. The signed minutes, together with the report form from the social aid representative and any material evidence the applicant might have handed in, are then included in the case file, which normally remains with the same caseworker or, in the case of a "pooly-interview", is passed on to the official responsible for taking the decision. During the process of taking the written decision, caseworkers might undertake further investigations with the Swiss embassies in the applicants' countries of origin, have documents tested for their authenticity, order a LINGUA report or a wrist bone analysis (the latter is done in order to find out whether the applicant is "really" a minor) ${ }^{22}$ or consult a "country analyst", for instance. ${ }^{23}$ Once the caseworker has made the decision, it must be checked and double-signed by the head of the section or their proxy before it is sent by post to the asylum seeker or their legal representative. The SEM official's involvement is then usually over except in case of an appeal. In case of an appeal, the FAC invites the SEM (through the official in charge of the 'case') to hand in an official statement concerning the

\footnotetext{
${ }^{21} \mathrm{https}$ ///www.refugeecouncil.ch/asylum-law/asylum-procedure-until-march-2019/social-aid-represent ation.html, last accessed 02.02.2020.

${ }^{22}$ For a description of this method, see Andreas Schmeling et al. (2003: 164).

${ }^{23}$ These kinds of investigations are discussed in more detail in Chapter 4.
} 
SEM's stance on the applicant's reasons for appeal. If the SEM's original decision is upheld by the court or if the decision is not appealed against in the first place (e.g. because it is a positive decision, the deadline for appeal is too short or the applicants do not find a legal advisor willing to help and/or represent them), the decision obtains legal force (Rechtskraft). If asylum or temporary protection is granted, the responsibility is primarily passed on to the cantons. In case of a negative decision without temporary protection, the directorate of "International Cooperation" (a different directorate of the SEM) becomes responsible for organising the "return" of the rejected applicants and the cantons become responsible for organising the deportations.

From the above description, we can see that asylum determination in the SEM fits an inquisitorial style of decision-making, one of two main types of decision-making which Mirjan Damaška distinguishes, the other one being adversarial decision-making (1986: 3). Rebecca Hamlin contrasts the two styles as follows:

The adversarial style takes the shape of a triad: two disputants arguing their respective cases before a passive judge, who must resolve the dispute by deciding which case is more persuasive [...] Unlike this courtroom-like setting, inquisitorial hearings are designed to be nonadversarial and nonlegalistic, taking the form of a dyad between the person whose fate is to be decided and the person deciding it. The inquisitorial decision maker engages in a conversation with the parties, and the facts must be discovered through a collaborative process of research and questioning. (2014: 18)

The inquisitorial style appears to be common for the initial stages in most asylum determination procedures in the Global North (see Hamlin 2014; Johannesson 2017: 13). Second-instance proceedings, in turn, tend to be more adversarial. In Switzerland, on appeal level, the appellant and the SEM both submit their opinions or "versions of the story" (Hamlin 2014: 18) in writing to the Federal Administrative Court, with the whole proceedings from then on taking place via written documents and briefs. While in theory the judges at the Federal Administrative Court would have the possibility to conduct court hearings, in practice this is not done. Instead, the judges sometimes send out written questionnaires to the appellants, but, mostly, their work consists of analysing the documents handed in at appeal level as well as those from the first-instance proceedings, including the minutes from the asylum interviews. Furthermore, they sometimes also request information or ask for assessments from the in-house "country analysts". Hence, in this regard, their role to some extent also remains inquisitorial. 
Robert Kagan suggests an additional way of distinguishing between different models of decision-making, namely according to how "formal" or "informal" they are and whether they are organised in a more "hierarchical and centralised" or "fragmented and participatory" way, the latter referring to "multiple disputing parties" participating in the proceedings (Hamlin 2014: 19; see Kagan 2001: 9-10). By "informal" he means that decision-making is mainly "based on discretion and case-by-case considerations" while "formal" decision-making is "based on legal rules and precedents" (Hamlin 2014: 19; see Kagan 2001: 9-10). Apart from being clearly inquisitorial, I would argue that asylum decision-making in the SEM tends more towards being "formal" as well as "hierarchical and centralised", which Robert Kagan refers to as "bureaucratic legalism" (2001: 10). Rules, institutional guidelines_or "secondary application norms", as Jonathan Miaz calls them (2017: 291-297)—as well as precedents set by the Federal Administrative Court significantly guide SEM decision-makers' everyday practices. However, at the same time, decision-making in the SEM is also to some extent what Kagan calls "informal": officials deal with asylum applications on a case-by-case basis, actively investigating the 'cases' they are dealing with, selecting which rules to apply in particular situations and interpreting those rules in the course of their application. With its centralised organisation that is then segmented into "decentralised branch-offices" (Schneider 2019: 288) and rather clear-cut institutional hierarchies, the SEM, furthermore, seems to closely resemble first-instance asylum organisations in other Western European civil law countries, such as the Bundesamt für Fremdenwesen und Asyl in Austria (see Dahlvik 2018), the Bundesamt für Migration und Flüchtlinge in Germany (see Probst 2012; Schneider 2019) or the Office Français de Protection des Réfugiés et Apatrides in France (Probst 2012).

\section{The Swiss Asylum Act}

Decision-making in the SEM ultimately comes down to assigning asylum claimants to one of four legal categories, each of which is attached to a set of rights and obligations. As Fig. 3.4 shows, these categories are: refugee with asylum, refugee with temporary admission, non-refugee with temporary admission (mostly on the basis of so-called "humanitarian grounds") and non-refugee without temporary admission.

In order to assign asylum seekers to one of the four categories a sequence of yes or no questions must be answered by the decision-makers. The two main eligibility questions decision-makers deal with are: Are applicants eligible to 


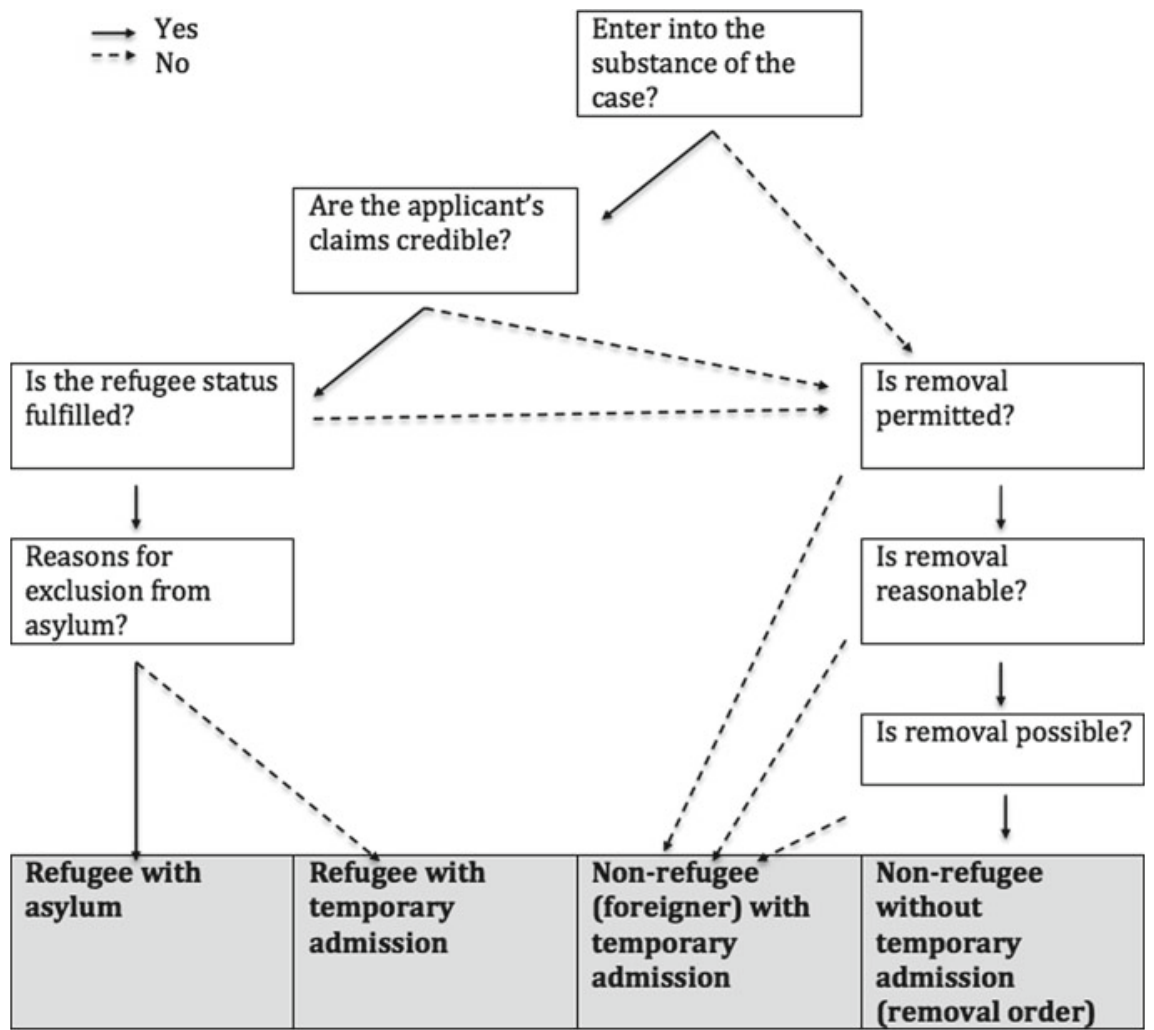

Fig. 3.4 Flowchart of asylum decision-making based on the Swiss Asylum Act (Source Own diagram). This diagram is my synthesis of flowcharts I received in three separate training modules that I attended in the SEM

asylum and, if not, are they eligible to temporary protection? Both these eligibilities are enshrined in the Swiss Asylum Act (AsylA). In order to receive asylum, asylum seekers must be recognised as refugees. Drawing on the 1951 Refugee Convention, refugees in the Swiss Asylum Act are defined as "persons who in their native country or in their country of last residence are subject to serious disadvantages or have a well-founded fear of being exposed to such disadvantages for reasons of race, religion, nationality, membership of a particular social group or due to their political opinions" (Art. 3, paragraph 1, AsylA). Article 3 AsylA, furthermore, elaborates on what is included in "serious disadvantages": namely "a threat to life, physical integrity or freedom as well as measures that exert intolerable psychological pressure" (Art. 3, paragraph 2, AsylA). In addition, it notes that "[m]otives for seeking asylum specific to women must be taken into account" (ibid.). In 2012, following a public referendum, the refugee category was made more restrictive by 
excluding certain groups of people from it. For this purpose, two new paragraphs were added to Article 3 of the Asylum Act. Paragraph 3 now states that "[p]ersons who are subject to serious disadvantages or have a well-founded fear of being exposed to such disadvantages because they have refused to perform military service or have deserted are not refugees" (Art. 3, paragraph 3, AsylA). And paragraph 4 lays down that "[p]ersons who claim grounds based on their conduct following their departure that are neither an expression nor a continuation of a conviction already held in their native country or country of origin are not refugees" (Art. 3, paragraph 4, AsylA). These restrictions mainly came about as a reaction to applications from Eritreans seeking protection after having deserted from the military and, thus, having fled from probable life-long service, and as a reaction to people claiming asylum on the basis of persecution due to their conversion to Christianity, for example.

In Fig. 3.4, we can see that in some cases, while people are recognised as refugees, they are, nevertheless, excluded from asylum. This is, on the one hand, done on the basis of Article 1F of the 1951 Refugee Convention which states that

The provisions of this Convention shall not apply to [...] person[s] with respect to whom there are serious reasons for considering that: (a) [they have] committed a crime against peace, a war crime, or a crime against humanity, as defined in the international instruments drawn up to make provision in respect of such crimes; (b) [they have] committed a serious non-political crime outside the country of refuge prior to his admission to that country as a refugee; (c) [they have] been guilty of acts contrary to the purposes and principles of the United Nations. (Article 1F, 1951 Convention relating to the Status of Refugees)

On the other hand, the Swiss Asylum Act itself sets out reasons for excluding refugees from asylum. Thus, Article 53 determines that "[r]efugees shall not be granted asylum if: a. they are unworthy of it due to serious misconduct; b. they have violated or endangered Switzerland's internal or external security" (Art. 53, AsylA) and Article 54 states that "[r]efugees shall not be granted asylum if they became refugees in accordance with Article 3 only by leaving their native country or country of origin or due to their conduct after their departure" (Art. 54, AsylA).

A major precondition for being recognised as a refugee and receiving asylum is that applicants "prove or at least credibly demonstrate their refugee status" (Art. 7, paragraph 1, AsylA). Article 7 stipulates that one's "[r] efugee status is credibly demonstrated if the authority regards it as proven on the 
balance of probabilities [and that] [c]ases are not credible in particular if they are unfounded in essential points or are inherently contradictory, do not correspond to the facts or are substantially based on forged or falsified evidence" (Art. 7, paragraphs 2 and 3, AsylA). "On the balance of probabilities" seems to be a comparatively high standard of proof in asylum proceedings compared to that of other countries and the standard set by international law which 'merely' demands "a reasonable degree of likelihood" (see Good 2015; Kelly 2012; Sweeney 2009). Commonly, "on the balance of probabilities" is the standard of proof in civil law proceedings, and not in asylum procedures (see Kelly 2012: 764). Whether this is a translation problem - since English is not an official language of the Swiss Confederation - or whether the standard of proof is, at least in formal terms, indeed higher in Switzerland than in other countries is not possible for me to determine with certainty, but may be an important issue to be addressed by legal scholarship. In any case, being credible is "different both from 'being proven' and from 'being true"' (Sweeney 2009: 711). Claimants' eligibility to refugee status does not have to be "proven beyond reasonable doubt" and is not "immediately susceptible to positivistic proof" (Kelly 2012: 759, 264; see also Kelly 2011: 194). Hence, material evidence and witnesses that corroborate the ill treatment of asylum seekers are not a necessary requirement for being granted asylum (see Good 2011: 94). ${ }^{24}$

If asylum seekers are regarded as not being eligible to asylum, for instance because the claims are deemed non-credible, the caseworkers must decide whether the applicant should receive temporary admission on the basis of Article 83 of the Federal Act on Foreign Nationals (FNA). Temporary admission is granted to applicants "[i]f the enforcement of removal is not permitted [under international law], ${ }^{25}$ not reasonable [for humanitarian reasons] ${ }^{26}$ or not possible [for 'technical' reasons]" ${ }^{27}$ (Art. 83, paragraph 1, FNA). If any of these questions are answered with yes, the applicant is granted subsidiary protection. If the answer to all these questions is no, applicants receive a letter

\footnotetext{
${ }^{24}$ See also Anthony Good (2003: 4), Walter Kälin (1990: 299), Cécile Rousseau et al. (2002: 44) as well as the SEM "Asylum and Return Compendium": https://www.sem.admin.ch/dam/data/sem/asyl/ verfahren/hb/b/hb-b3-d.pdf, last accessed 10.02.2020.

25 "Enforcement is not permitted if Switzerland's obligations under international law prevent the foreign national from making an onward journey to their native country, to their country of origin or to a third country" (Art. 83, paragraph 3, FNA). The relevant international treaties this refers to are the European Convention on Human Rights, the United Nations Conventions relating to the Status of Refugees and the United Nations Convention on the Rights of the Child.

26 "Enforcement may be unreasonable for foreign nationals if they are specifically endangered by situations such as war, civil war, general violence and medical emergency in their native country or country of origin" (Art. 83, paragraph 4, FNA).

27 "Enforcement is not possible if the foreign national is unable to travel or be brought either to their native country or to their country of origin or a third country" (Art. 82, paragraph 2, FNA).
} 
informing them that they must leave Switzerland within a certain amount of time. With such "removal orders", the responsibility for the 'case' is passed on to another directorate of the SEM, that of "International Cooperation", and to the cantonal authorities who must decide whether to detain or to deport the people whose asylum applications have been rejected, and hence organise these actions. Thus, this no longer falls within the responsibility of asylum decision-makers.

\section{References}

Asylum Act, (AsylA), of 26 June 1998 (Status as of 1 January 2020). 142.31.

Asylverordnung 1 über Verfahrensfragen, (Asylverordnung 1, AsylV 1), of 11 August 1999 (Status as of 1 January 2020). 142.311.

Boswell, Christina. 2003. European Migration Policies in Flux: Changing Patterns of Inclusion and Exclusion. London: Wiley-Blackwell.

Boswell, Christina. 2007. "Migration Control in Europe After 9/11: Explaining the Absence of Securitization." Journal of Common Market Studies 45 (3): 589-610. https://doi.org/10.1111/j.1468-5965.2007.00722.x.

Convention on the Rights of the Child, adopted on 20 November 1989. https:// www.ohchr.org/en/professionalinterest/pages/crc.aspx, last accessed February 10, 2020.

Convention relating to the Status of Refugees, adopted on 28 July 1951. https:// www.ohchr.org/en/professionalinterest/pages/statusofrefugees.aspx, last accessed February 10, 2020.

Dahlvik, Julia. 2018. Inside Asylum Bureaucracy: Organizing Refugee Status Determination in Austria. IMISCOE Research Series. Cham: Springer.

Damaška, Mirjan R. 1986. The Faces of Justice and State Authority. New Haven: Yale University Press.

D’Amato, Gianni. 2008. "Une revue historique et sociologique des migrations en Suisse." Annuaire Suisse de politique de développement 27 (2): 169-187. http:// journals.openedition.org/aspd/511, last accessed February 10, 2020.

Däpp, Heinz. 1984. "Bankrott einer staatspolitischen Maxime.” In Asylpolitik gegen Flüchtlinge, edited by Heinz Däpp, and Rudolf Karlen, 211-226. Basel: Lenos.

Efionayi-Mäder, Denise. 2003. Asylpolitik der Schweiz 1950-2000. ASYL 2/03: 3-9.

Eule, Tobias G. 2014. Inside Immigration Law: Migration Management and Policy Application in Germany. Farnham: Ashgate.

Eule, Tobias G., Lisa Marie Borrelli, Annika Lindberg, and Anna Wyss. 2019. Migrants Before the Law: Contested Migration Control in Europe. Cham: Palgrave Macmillan.

European Convention on Human Rights. https://www.echr.coe.int/Documents/ Convention_ENG.pdf, last accessed February 10, 2020. 
Fassin, Didier. 2005. "Compassion and Repression: The Moral Economy of Immigration Policies in France." Cultural Anthropology 20 (3): 362-387. https://doi. org/10.1525/can.2005.20.3.362.

Fassin, Didier. 2007. "Humanitarianism as a Politics of Life." Public Culture 19 (3): 499-520. https://doi.org/10.1215/08992363-2007-007.

Fassin, Didier. 2012. Humanitarian Reason: A Moral History of the Present. Berkeley: University of California Press.

Fassin, Didier. 2016a. "Vom Rechtsanspruch zum Gunsterweis. Zur moralischen Ökonomie der Asylvergabepraxis im heutigen Europa." Translated by Frank Jakubzik. Mittelweg 36 1: 62-78.

Fassin, Didier. 2016b. "From Right to Favor: The Refugee Question as Moral Crisis." The Nation. https://www.thenation.com/article/from-right-to-favor/, last accessed February 11, 2020.

Fassin, Didier, and Carolina Kobelinsky. 2012. "How Asylum Claims Are Adjudicated: The Institution as a Moral Agent." Revue française de sociologie 53 (4): 444-472. https://doi.org/10.3917/rfs.534.0657.

Federal Act on Administrative Procedure, (Administrative Procedure Act APA), of 20 December 1968 (Status as of 1 April 2019). 172.021.

Federal Act on Foreign Nationals, (Foreign Nationals Act, FNA), of 16 December 2005 (Status as of 1 December 2019). 142.20.

Fuglerud, Oivind. 2004. "Constructing Exclusion: The Micro-Sociology of an Immigration Department." Social Anthropology 12 (1): 25-40. https://doi.org/ 10.1111/j.1469-8676.2004.tb00088.x.

Gill, Nick, and Anthony Good. 2019. "Introduction.” In Asylum Determination in Europe: Ethnographic Perspectives, edited by Nick Gill, and Anthony Good, 1-26. Cham: Palgrave Macmillan.

Good, Anthony. 2003. "Anthropologists as Experts: Asylum Appeals in British Courts." Anthropology Today 19 (5): 3-7. https://doi.org/10.1111/1467-8322. 00215.

Good, Anthony. 2011. "Witness Statement and Credibility Assessments in the British Asylum Courts." In Cultural Expertise and Litigation, edited by Livia Holden, 94-122. Abingdon, New York: Routledge.

Good, Anthony. 2015. “The Benefit of the Doubt' in British Asylum Claims and International Cricket." In Of Doubt and Proof: Ritual and Legal Practices of Judgement, edited by Daniela Berti, Anthony Good, and Gilles Tarabout, 119-140. London: Routledge.

Hamlin, Rebecca. 2014. Let Me Be a Refugee: Administrative Justice and the Politics of Asylum in the United States, Canada, and Australia. Oxford: Oxford University Press.

Haug, Werner. 1984. "Asylpolitik im historischen Rückblick.” In Asylpolitik gegen Flüchtlinge, edited by Heinz Däpp, and Rudolf Karlen, 127-175. Basel: Lenos.

Huysmans, Jef. 2000. "The European Union and the Securitization of Migration." Journal of Common Marked Studies 38 (5): 751-777. https://doi.org/10.1111/ 1468-5965.00263. 
Johannesson, Livia. 2017. In Courts We Trust: Administrative Justice in Swedish Migration Courts. Stockholm University. http://www.diva-portal.org/smash/get/ diva2:1072557/FULLTEXT01.pdf, last accessed February 3, 2020.

Jubany, Olga. 2017. Screening Asylum in a Culture of Disbelief: Truths, Denials and Sceptical Borders. Cham: Palgrave Macmillan.

Kagan, Robert. 2001. Adversarial Legalism: The American Way of Law. Cambridge: Harvard University Press.

Kälin, Walter 1990: Grundriss des Asylverfahrens. Basel: Helbing \& Lichtenhahn.

Kelly, Tobias. 2011. "The Legalization of Human Rights and the Protection of Torture Survivors: Asylum, Evidence and Disbelief." In Are Human Rights for Migrants? Critical Reflections on the Status of Irregular Migrants in Europe and the United States, edited by Marie-Bénédicte Dembour, and Tobias Kelly, 1-22. New York: Routledge.

Kelly, Tobias. 2012. "Sympathy and Suspicion: Torture, Asylum, and Humanity." Journal of the Royal Anthropological Institute 18 (4): 753-768. https://doi.org/10. 1111/j.1467-9655.2012.01790.x.

Kobelinsky, Carolina. 2015. "In Search of Truth: How Asylum Applications Are Adjudicated." In At the Heart of the State: The Moral World of Institutions, edited by Didier Fassin, 67-92. London: Pluto Press.

Kopp, Elisabeth. 1987. "Die Schweiz im weltweiten Flüchtlingsproblem." In Zeit der Flüchtlinge, edited by Urs Gfeller, 109-124. Zürich: Edition M.

Liodden, Tone Maia. 2016. "The Burdens of Discretion: Managing Uncertainty in the Asylum Bureaucracy." PhD diss. (unpublished), University of Oslo.

Loher, David. 2020. "Governing the Boundaries of the Commonwealth: The Case of So-Called Assisted Voluntary Return Migration." In The Bureaucratic Production of Difference, edited by Julia Eckert, 113-134. Bielefeld: transcript.

Maillard, Alain, and Christophe Tafelmacher. 1999. "Faux réfugiés"? La politique Suisse de dissauasion d'asile, 1979-1999. Lausanne: Editions d'en bas.

Meiner, Beat. 2007. "Asyl im Würgegriff der Politik: Aktuelle Probleme der Flüchtlingshilfe." In Verdrängung, Verklärung, Verantwortung: Schweizerische Flüchtlingspolitik in der Kriegs- und Nachkriegszeit 1940-2007, edited by Helena Kanyar Becker, 119-122. Basel: Universitätsbibliothek Basel.

Miaz, Jonathan. 2017. "Politique d'asile et sophistication du droit: Pratiques administratives et défense juridique des migrants en Suisse (1981-2015)." PhD diss. (unpublished), University of Lausanne and University of Strasbourg.

Parini, Lorena, and Matteo Gianni. 2005. "Enjeux et modifications de la politique d'asile en Suisse de 1956 à nos jours." In Histoire de la politique de migration, d'asile et d'intégration en Suisse depuis 1948, edited by Hans Mahnig, 189-252. Zurich: Editions Seismo.

Piguet, Etienne. 2006. Einwanderungsland Schweiz: Fünf Jahrzehnte halb geöffnete Grenzen. Bern: Haupt. 
Piguet, Etienne. 2009. L'immigration en Suisse. Soixante ans d'entrouverture. Lausanne: Presses polytechniques et universitaires romandes.

Poertner, Ephraim. 2017. "Governing Asylum through Configurations of Productivity and Deterrence: Effects on the Spatiotemporal Trajectories of Cases in Switzerland." Geoforum 78: 12-21. https://doi.org/10.1016/j.geoforum.2016. 11.004.

Poertner, Ephraim. 2018. "Re-cording Lives: Governing Asylum in Switzerland and the Need to Resolve." PhD diss. (unpublished), University of Zurich.

Probst, Johanna. 2012. Instruire la demande d'asile: étude comparative du processus décisionnel au sein de l'administration allemande et française. Science politique, Université de Strasbourg. https://tel.archives-ouvertes.fr/tel-00985215/doc ument, last accessed February 03, 2020.

Rousseau, Cécile, François Crépeau, Patricia Foxen, and France Houle. 2002. "The Complexity of Determining Refugeehood: A Multidisciplinary Analysis of the Decision-making Process of the Canadian Immigration and Refugee Board.” Journal of Refugee Studies 15 (1): 43-70. https://doi.org/10.1093/jrs/15.1.43.

Schmeling, Andreas, Andreas Olze, Walter Reisinger, Friedrich W. Rösing, and Gunther Geserick. 2003. "Forensic Age Diagnostics of Living Individuals in Criminal Proceedings." HOMO_Journal of Comparative Human Biology 54 (2): 162-169. https://doi.org/10.1078/0018-442X-00066.

Schneider, Stephanie. 2019. "Becoming a Decision-Maker, or: 'Don't Turn Your Heart into a Den of Thieves and Murderers." In Asylum Determination in Europe: Ethnographic Perspectives, edited by Nick Gill, and Anthony Good, 285-305. Cham: Palgrave Macmillan.

Schweizerische Flüchtlingshilfe SFH, ed. 2009. Handbuch zum Asyl- und Wegweisungsverfahren. Bern: Haupt.

Sille, Irina. 2016. "Die Konstruktion der vorläufigen Aufnahme im Asyl- und Ausländergesetz: Eine Analyse des Gesetzgebungsdiskurses zwischen 1985 und 2012." Master thesis. Neuchâtel: Université de Neuchâtel, Faculté des lettres et sciences humaines. http://doc.rero.ch/record/277779/files/Sille_Irina___Die_ Konstruktion_der_vorl_ufigen_Aufhnahme_UNINE_MEMOIRE_2016.pdf, last accessed February 10, 2020.

Stünzi, Robin. 2010. "La migration, une menace? Contexte et enjeux autour de la 'sécuritisation' de la migration." Tangram 26: 97-101.

Sweeney, James A. 2009. "Credibility, Proof and Refugee Law." International Journal of Refugee Law 21 (4): 700-726. https://doi.org/10.1093/ijrl/eep027.

UNHCR. 1992. Handbook on Procedures and Criteria for Determining Refugee Status under the 1951 Convention and the 1967 Protocol Relating to the Status of Refugees. Geneva: United Nations High Commissioner for Refugees.

Weber, Max. 2013 (1978). Economy and Society. Edited by Guenther Roth, and Claus Wittich. Berkeley: University of California Press. 
Zetter, Roger. 2007. "More Labels, Fewer Refugees: Remaking the Refugee Label in an Era of Globalization." Journal of Refugee Studies 20 (2): 172-192. https://doi. org $/ 10.1093 /$ jrs/fem011.

Zimmermann, Susan E. 2011. "Reconsidering the Problem of 'Bogus' Refugees with 'Socio-economic Motivations' for Seeking Asylum." Mobilities 6: 335-352. https://doi.org/10.1080/17450101.2011.590034.

Open Access This chapter is licensed under the terms of the Creative Commons Attribution 4.0 International License (http://creativecommons.org/licenses/by/4.0/), which permits use, sharing, adaptation, distribution and reproduction in any medium or format, as long as you give appropriate credit to the original author(s) and the source, provide a link to the Creative Commons license and indicate if changes were made.

The images or other third party material in this chapter are included in the chapter's Creative Commons license, unless indicated otherwise in a credit line to the material. If material is not included in the chapter's Creative Commons license and your intended use is not permitted by statutory regulation or exceeds the permitted use, you will need to obtain permission directly from the copyright holder.

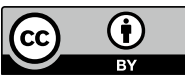

